\title{
沿岸におけるうねり性波浪による水位変動の検証
}

\author{
河合 $\quad$ 雅司 $^{1} \cdot$ 後藤 $\quad$ 佑介 ${ }^{2} \cdot$ 北村 $\quad$ 康司 $^{3} \cdot$ 川口 $\quad$ 清司 ${ }^{4}$

\section{Verification of Water Level Fluctuations Off the Coast by Swells}

\author{
Masashi KAWAI, Yusuke GOTOH, Yasushi KITAMURA
}

\author{
and Kiyoshi KAWAGUCHI
}

\begin{abstract}
Wave disasters caused by large swells have occurred on the coast of Toyama Wan, and these swells have been studied by many researchers. As a result of the studies, it is known that water level fluctuations with periods of several minutes occur off the coast of the Toyama Wan, when large swells invade the Toyama Wan. But generation mechanism of the water level fluctuations does not become clear.

And so, the generation mechanism was investigated by wave observations off the coast of Toyama Wan and wave generating experiments using water tank. As the results, they became clear that the water level fluctuations with periods of several minutes are proper oscillations in horizontal shallow water off coast, and mean water level in a horizontal shallow water jutting out from a coast rises several meters due to swells invading the horizontal shallow water.
\end{abstract}

Keywords : oceanography, swell, proper oscillation, water level fluctuation, Toyama Wan キーワード: 海象, うねり性波浪, 固有振動, 水位変動, 富山湾

\section{1. はじめに}

富山湾沿岸では、例年 10 月から 3 月にかけて押 し寄せるうねり性波浪(寄り回り波)により、たびた び波浪災害が発生している。このため、富山高等専 門学校では、船舶の安全運航等の視点からこの波の 研究に取り組んでおり、吉田(1987)は、1981 年 12 月 16 日に富山湾に押し寄せた寄り回り波を航空機 から観測していた時に、魚津から富山へかけての沖 合で寄り回り波よりもはるかに周期の長い沿岸から 沖合へ向から波が、沿岸部に存在していることを発 見した ${ }^{(1)}$ 。この波は、うねり性波浪の侵入に伴い生 じた長周期波であると思われる(2)。数分周期の長周 期波の発生原因については、うねり性波群が沿岸部
で変形、砕波することにより、うねり性波群に拘束 された長周期波成分が解放されることにより生じる と考えられているが (3) (4)、必ずしも明確には分かっ ていない。

富山高等専門学校は、気象海象機器メーカーであ る(株) ソニックと波浪災害を防止するために、富山 湾におけるう衫り性波浪に関する共同研究を行って おり、また、新潟港湾空港技術調査事務所では、港 湾構造物の効率的かつ効果的な整備・維持管理を目 的として富山湾のうねり性波浪の研究を進めている。 そして、うねり性波浪が富山湾に侵入することによ り生じる長周期波は、船の係留や港湾の構造物に影 響を及ぼすと考えられる。そこで、うねり性波浪に
1 正会員 富山高等専門学校商船学科

2 非会員 新潟港湾空港技術調査事務所

非会員 株式会社ソニック海象機器部

4 非会員 富山大学大学院理工学研究部
（干933-0293 射水市海老江練合 1-2） mkawai@nc-toyama. ac. jp （下951-8011 新潟市中央区入船町 4-3778）gotoh-y84qc@pa.hrr.mlit.go.jp （干190-0012 立川市曙町 1-18-2） yasushi-kitamura@u-sonic. co.jp

（干930-0887＼cjkstart富山市五福 3190）kawaguti@eng. u-toyama. ac.jp 
伴い沿岸部で発生する数分周期の水位変動 (長周期 波)の発生メカニズムについて詳しく調べるために、 新潟港湾空港技術調査事務所および(株)ソニックと の共同研究として、富山湾沿岸部での波浪(水位) 観 測の実施、および、造波実験を行った。これらの結 果について、以下に報告する。

\section{2. 富山湾治岸における水位観測}

本研究では、2014年 12 月から 2015 年 1 月までの、 四方沖合の NOWPHAS 富山波浪計による水位データ、 岩瀬浜沖の水位データを用いて、うねり性波浪に伴 う沿岸域の水位変動について調べた。本研究で用い た NOWPHAS 富山波浪計データは、国土交通省港湾局 によって観測され、港湾空港技術研究所で処理され たものである。

四方沖の NOWPHAS 富山波浪計 (36 46” 51”N, 137 $12^{\prime} 06^{\prime \prime} \mathrm{E}$, 水深 20m) と岩瀬浜沖の波浪計 (36 $46^{\prime} 18^{\prime \prime} \mathrm{N}, 137^{\circ} 15^{\prime} 00^{\prime \prime} \mathrm{E}$ ，水深 $\left.11 \mathrm{~m}\right)$ は、0.5 秒毎に水 圧を測定して海面までの距離を観測している。富山 波浪計は海底谷の斜面の上、岩瀬浜沖の波浪計はな だらかな水平浅瀬域に設置されている。富山湾にお ける富山波浪計、および岩瀬浜沖の波浪計の位置を Fig. 1 に示す。

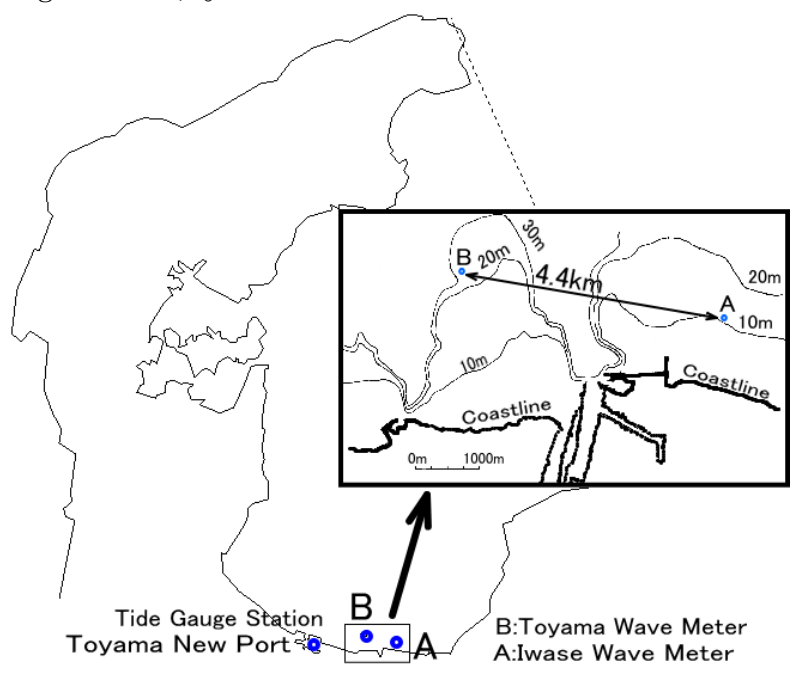

Fig.1 The map of wave observation points in Toyama Wan

\section{3. 観測水位の解析}

観測された水位データについては、気象庁が公開 している富山の潮汐定数を用いて、天文潮汐による 水位変動を除去した。約 145.6 時間分の観測データ をスペクトル解析することにより、数分周期の水位 変動とうねり性波浪の関係について調べた結果、次 のことが確認できた。
(1) 岩瀬浜沖における 2015 年 1 月 7 日〜 12 日と 1 月 13 日〜18 日の波を比較すると、Fig. 2 と Fig. 3 に示 すようにうねり性波浪のスペクトルの形が異なって いても、Fig. 4 と Fig. 5 に示すように数分周期の波 のスペクトルの形はほぼ同じである。

(2) 周期 10〜20 秒のスペクトル值の合計をSAとし、 Fig. 2 の SA を、Fig. 3 の SA で割った平方根は 2.1 となる。また、周期 60〜340.9 秒のスペクトル值の 合計を SB とし、Fig. 4 の SB を、Fig. 5 の SB で割っ た平方根は 2.7 となる。つまり、周期 10 数秒のうね り性波浪の波高と周期数分の波の波高は、ほぼ比例 している。(う衫り性波浪の波高が 2.1 倍になると、 周期数分の波の波高は 2.7 倍になる。)

(3) $4.4 \mathrm{~km}$ 離れた四方沖 (B 点) と岩瀬浜沖 (A 点) にお いて、うねり性波浪のスペクトル值は B 点の方が大 きいが (Fig. 6, Fig. 7 参照)、数分周期の波のスペク トル值は A 点の方が大きい(Fig. 8, Fig. 9 参照)。

(4) 四方沖 (B 点) と岩瀬浜沖 (A 点) の数分周期の波の スペクトルの形は異なっている(Fig. 8,Fig.9 参照)。

これらの結果から、沿岸部における数分周期の波 は、うねり性波浪が沿岸部のなだらかな水平浅瀬域 に侵入し変形、砕波する過程で、浅瀬域に生じた固 有振動であると考えることができる。

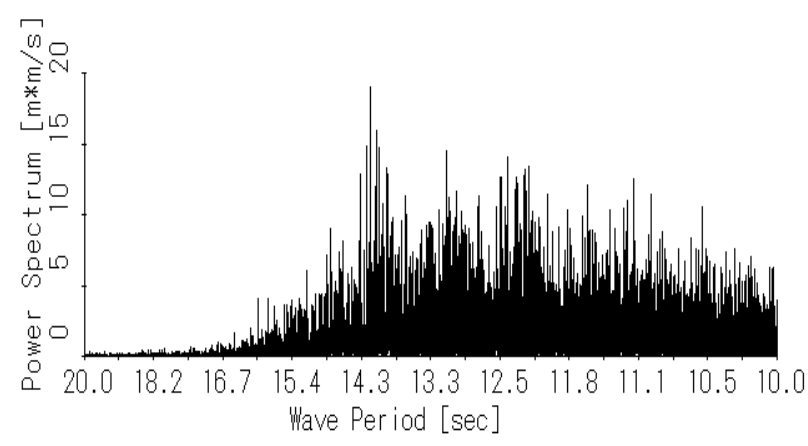

Fig. 2 Spectrum of swells with periods of $10 \mathrm{sec}$. to 20 sec. observed off Iwasehama from Jan. 7 to 12,2015

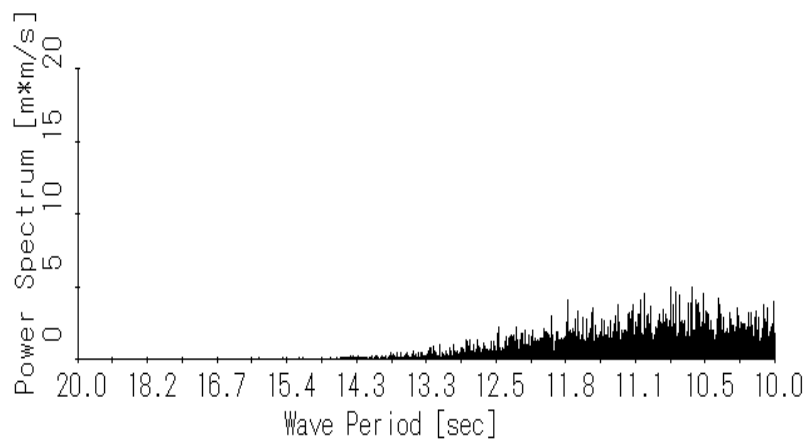

Fig.3 Spectrum of swells with periods of $10 \mathrm{sec}$. to $20 \mathrm{sec}$. observed off Iwasehama from Jan. 13 to 18,2015 


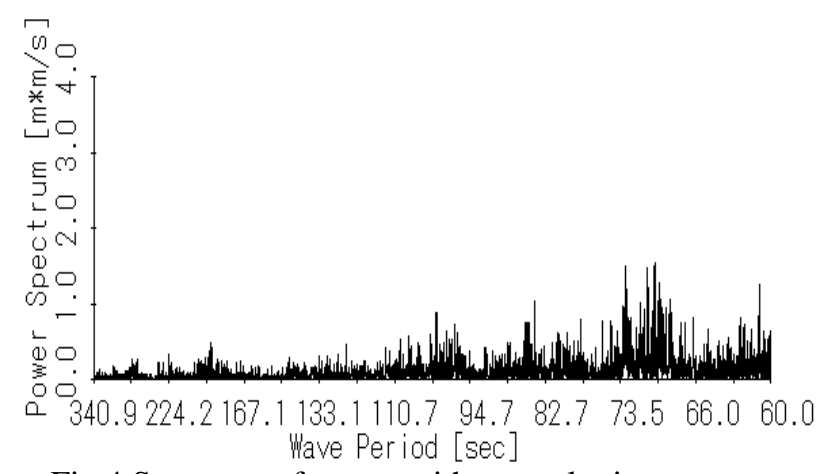

Fig.4 Spectrum of waves with several minute periods observed off Iwasehama from Jan. 7 to 12,2015

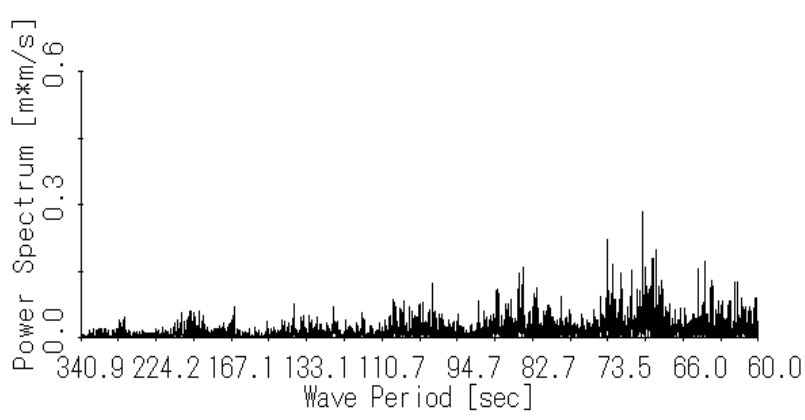

Fig.5 Spectrum of waves with several minute periods observed off Iwasehama from Jan. 13 to 18,2015

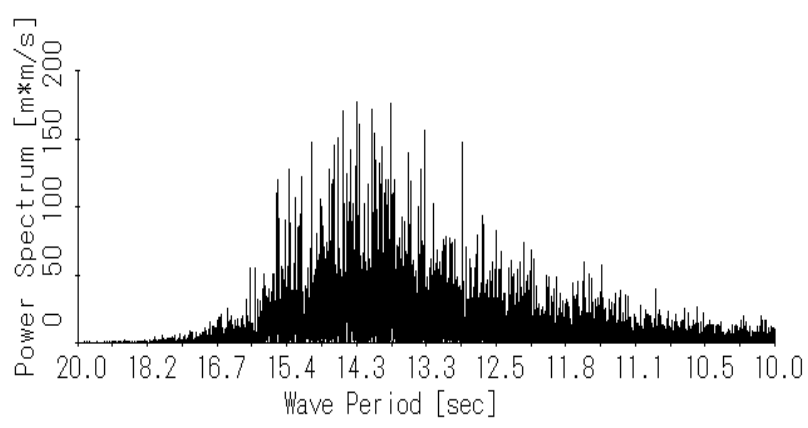

Fig.6 Spectrum of swells with periods of $10 \mathrm{sec}$. to $20 \mathrm{sec}$. observed off Yokata from Dec. 15 to 20,2014

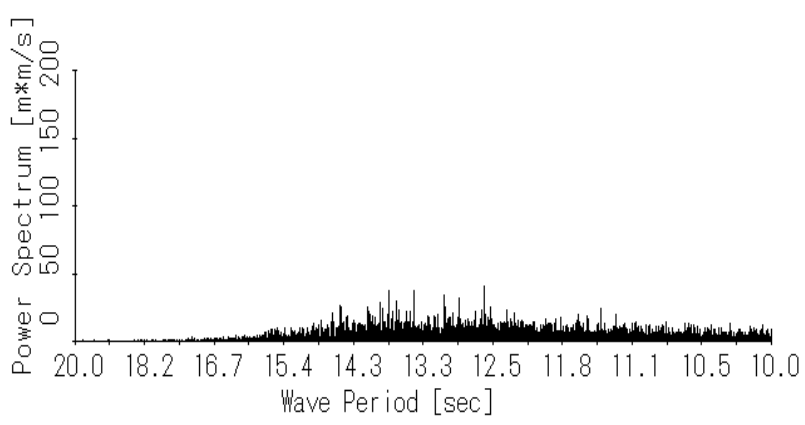

Fig.7 Spectrum of swells with periods of $10 \mathrm{sec}$. to $20 \mathrm{sec}$. observed off Iwasehama from Dec. 15 to 20,2014

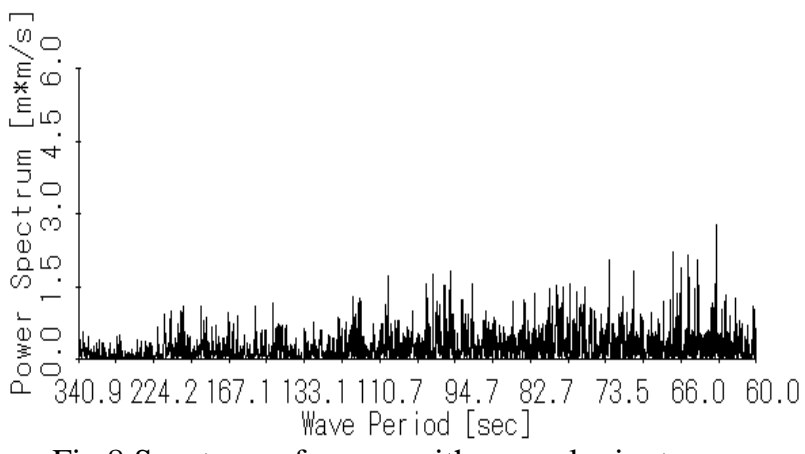

Fig.8 Spectrum of waves with several minute periods observed off Yokata from Dec. 15 to 20,2014

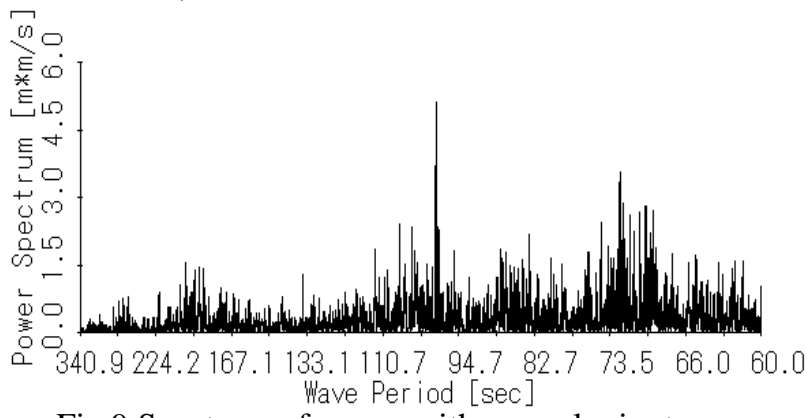

Fig.9 Spectrum of waves with several minute periods observed off Iwasehama from Dec. 15 to 20,2014

次に、数分周期の波の波高について考える。2014 年 12 月 15 日〜20日にかけて、岩瀬浜沖の数分周期 の波のスペクトル值が大きくなっており、最大で約 $5 \mathrm{~m}^{2} / \mathrm{s}$ である(Fig. 9 参照)。この時、岩瀬浜沖には最 大で平均波高 $2.6 \mathrm{~m}$ のうねり性波浪が押し寄せてい た。Fig. 7 より、この時のうねり性波浪のスペクト ル值は、最大で約 $35 \mathrm{~m}^{2} / \mathrm{s}$ であり、Fig. 9 より数分周 期のスペクトル值は最大で約 $5 \mathrm{~m}^{2} / \mathrm{s}$ である。従って、

$2.6\left(\mathrm{~m}^{2} / \mathrm{s}\right) /\left[35\left(\mathrm{~m}^{2} / \mathrm{s}\right) / 5\left(\mathrm{~m}^{2} / \mathrm{s}\right)\right]^{1 / 2}=1.0 \mathrm{~m}$

となり、この時の数分周期の波の波高は最大で $1 \mathrm{~m}$ 程度であったと考えられる。

\section{4. 水路による造波実験}

沿岸部における数分周期の波が水平浅瀬域におけ る固有振動であることを確かめるために行った造波 実験について、次に紹介する。2014 年 8 月 11 日か ら 15 日にかけて、港湾空港技術研究所の水路(長さ $35 \mathrm{~m}$ 、幅 $0.6 \mathrm{~m}$ ）を使用して造波実験を行った。富山湾 沿岸は一般に急深地形となっており、これをモデル 化して水路端に急斜面(勾配 1/3.8) を持つ水平浅瀬 域 (長さ $2 \mathrm{~m}$ 、幅 $0.6 \mathrm{~m}$ 、深さ $0.2 \mathrm{~m}$ )を作り規則波を入 射した。実験の概要図をFig. 10 に示す。なお、本実 験で想定する縮尺は $1 / 100$ である。 


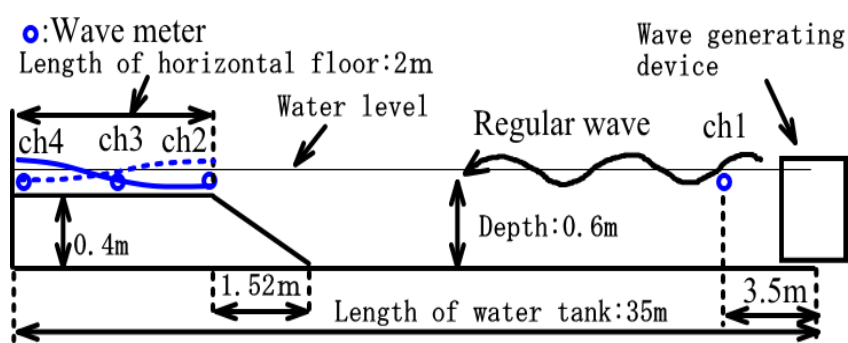

Fig.10 The description of wave making experiment

水路内に造波装置を使用して、沖 (ch1) で周期 0.8 秒 $\sim 1.51$ 秒 (波長 $1 \mathrm{~m} \sim 3 \mathrm{~m}$ ) 、波高 $3 \mathrm{~cm} \sim 9 \mathrm{~cm}$ の 6 種類 の規則波を 10 分間発生させ、 4 台の波高計(波高計 (ch1) : 沖合, 波高計 (ch2) : 入口, 波高計 (ch3) : 中央, 波高計 (ch4) : 奥) で、0.05 秒毎に 10 分間水位観測を 実施し、一つの波高計につき 12000 個のデータを得 た。そして、スペクトル解析では $2^{13}=8192$ 個 (409. 6 秒間)のデータを使用し、次の時間について行った。
(1) 時間 1(Time 1)：25 秒 434.55 秒

(2) 時間 2(Time 2)：190. 45 秒 $６ 00$ 秒

スペクトル解析した結果をFig. 11 に示す。Fig. 11 において、黒は沖合 (ch1)、青は入口（ch2）、紫は中 央（ch3）、緑は奥（ch4）のスペクトルを示しており、 上図は時間 1、下図は時間 2 のスペクトルである。 Fig. 11 より、波高 $9 \mathrm{~cm}$ 、周期 1.51 秒の波を水平床に 侵入させた場合、水深 $0.2 \mathrm{~m}$ の水平床で、周期 6.7 秒の水位変動が生じ、その振幅は水平床上 (ch2 ch4) で大きく、沖合 (ch1) で小さい。さらに、固有振 動の位相を調べた結果、水平床上の水位は、水平床 中央付近に節 (Node) があり、水平床の奥と入口を腹 (Anti-node) として振動しており、さらに、そのスペ クトル值は時間とともに成長していることが確認で きた。
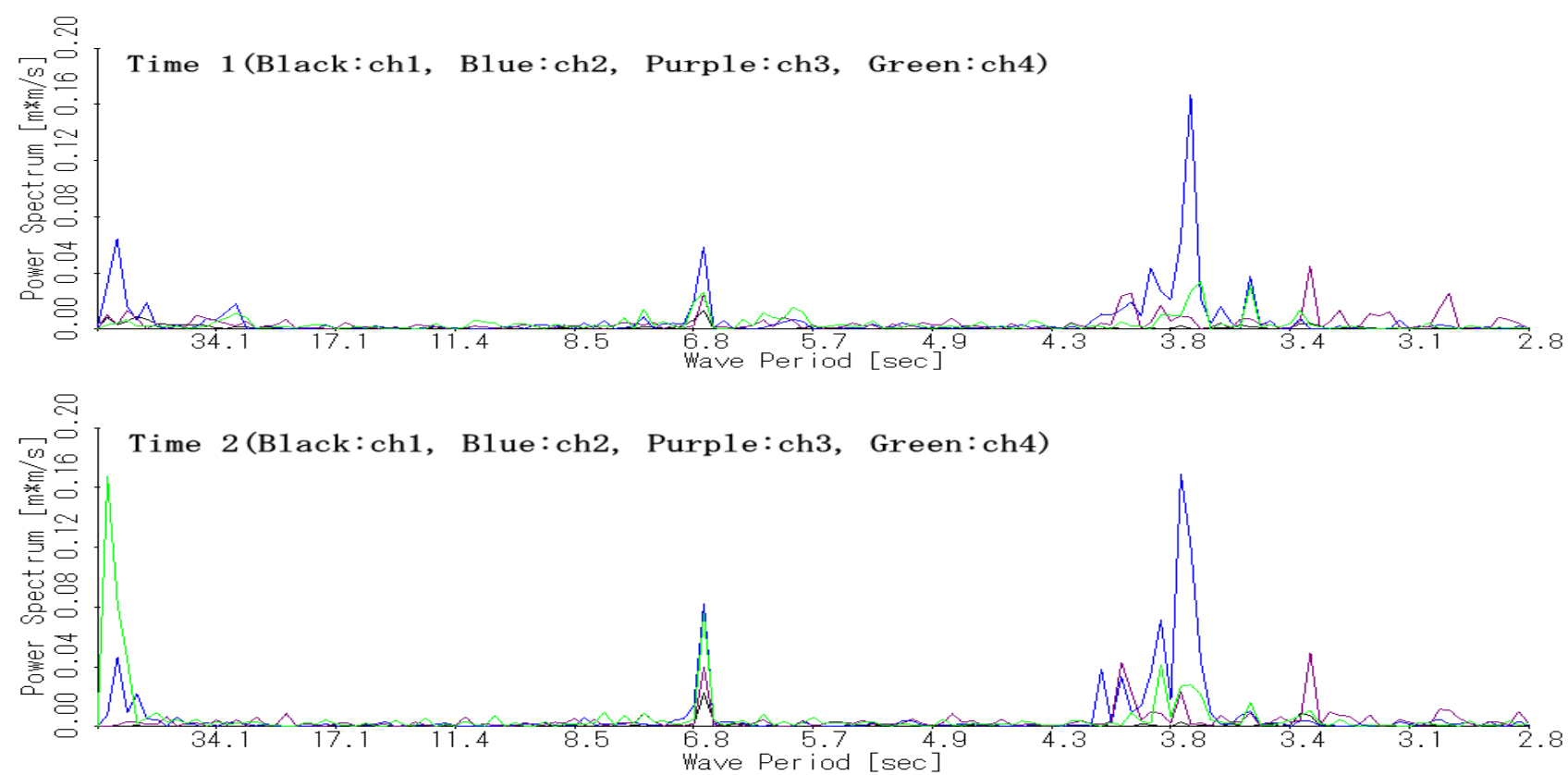

Fig.11 Power spectra of water levels at ch1,ch2,ch3 and ch4

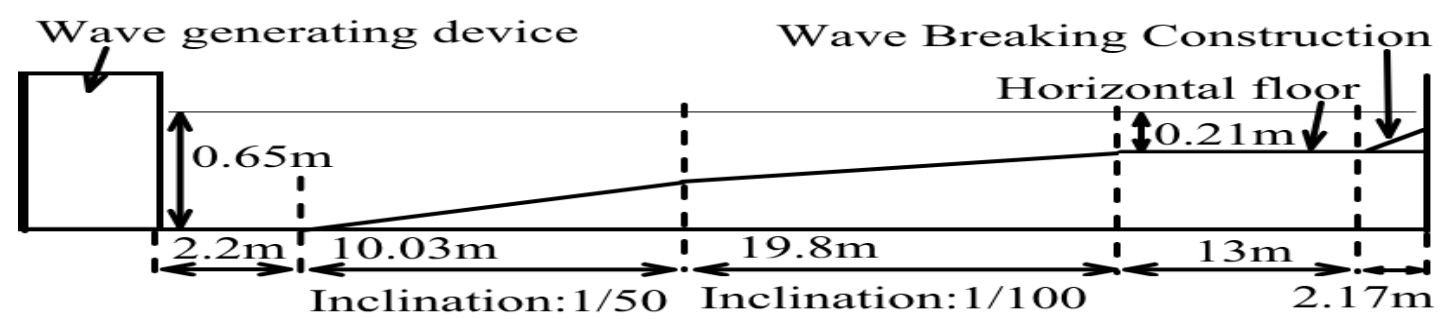

Fig.12 The cross section of plane water tank for wave generating experiment

\section{5. 平面水槽による造波実験}

2015 年 6 月と 9 月に新潟港湾空港技術調査事務所 の平面水槽 $(56.5 \mathrm{~m} \times 6.3 \mathrm{~m})$ を用いて、造波実験を行っ た。この平面水槽には、緩勾配 $(1 / 50$ と $1 / 100)$ の斜 面を有する水平浅瀬域が設置されており、さらに側
面は消波構造になっている。岩瀬浜沖 (Fig. 1 の A 点 参照) は緩勾配の地形であり、この平面水槽の地形は、 これに相当している。そして、水深 $0.21 \mathrm{~m}$ の水平浅 瀬域に規則波を入射し、浅瀬域で固有振動が生じる かどうか検証した。使用した平面水槽の断面図を 
Fig. 12 に示す。規則波 (沖 (ch3, ch4) で周期 1.48 秒 （波長 $3 \mathrm{~m}$ ）、波高 $5 \mathrm{~cm} 、 7 \mathrm{~cm} 、 9 \mathrm{~cm} 、 11 \mathrm{~cm} 、 13 \mathrm{~cm} 、 15 \mathrm{~cm})$ を 16 分間造波し、0.05 秒毎に波高計で水位を観測 した。解析は、造波装置を動かした 16 分間 (960 秒 間) 19200 個のデータのうち、 $2^{14}=16384$ 個 (819.2 秒 間)のデータを使用した。データ解析は、次の時間に ついて行った。

(a) 時間 A (Time A) : 30〜849.2 秒まで

(b) 時間 B (Time B) : 85〜904.2 秒まで

(c) 時間 C (Time C) : 140.8〜960 秒まで

なお、これらの実験に使用した平面水槽と水位観 測システムをFig. 13 に示す。

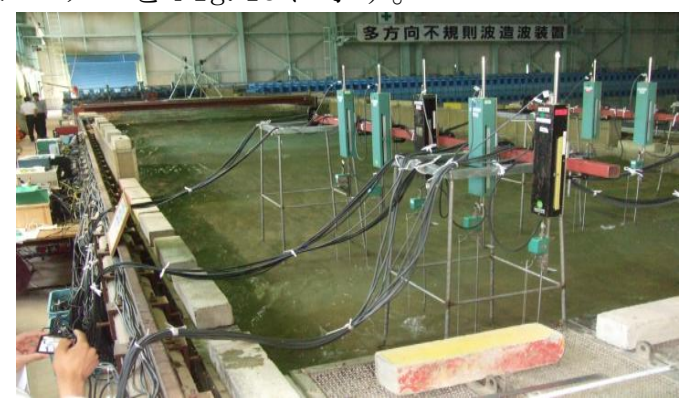

Fig.13 The plane water tank and wave level observation system in wave generating experiments

\section{1 造波実験 1}

造波実験 1 は、平面水槽内に仕切りを設け、幅 $5.6 \mathrm{~m}$ 、長さ $2 \mathrm{~m}$ 、水深 $0.21 \mathrm{~m}$ の水平床を設置し、規則 波 (周期 1.48 秒、波高 $5 \mathrm{~cm} \sim 15 \mathrm{~cm}$ ) を水平床に入射し た。この波の水平床上の波長は $1.99 \mathrm{~m}$ となる。た、 本実験で想定する縮尺は $1 / 100$ であり、造波実験 1 における水槽内の仕切と波高計設置位置を Fig. 14 に示す。

周期 1.48 秒、波高 $11 \mathrm{~cm}$ の規則波を水平床に入射 して得られた水位データをスペクトル解析した結果 をFig. 16 に示す。Fig. 16 は、ch16の時間A (青)、 時間 B (黒)、時間 C (紫)の水位データのスペクトル

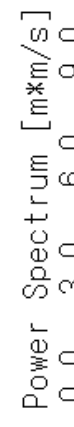

$$
\text { Ampli. }=7 \mathrm{~mm}
$$

18. $2 \mathrm{~s}$

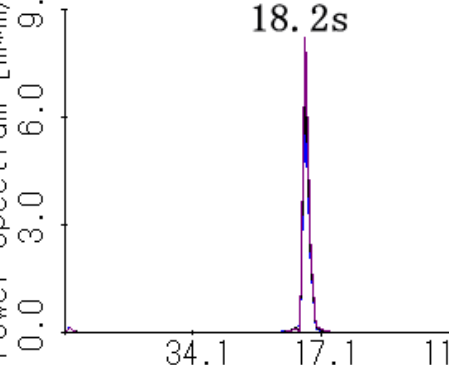

であり、18.2 秒および 9.1 秒周期の固有振動が存在 していることが分かる。また、時間Cのスペクトル は時間 Aのスペクトルよりピーク值が増大しており、 固有振動が時間とともに成長していることが確認で きた。なお、固有振動の位相も調べることにより、 18.2 秒周期の波の波高は $14 \mathrm{~mm}$ で、 $2 \mathrm{~m}$ の水平床上で 全体が上下に振動していることが分かった。

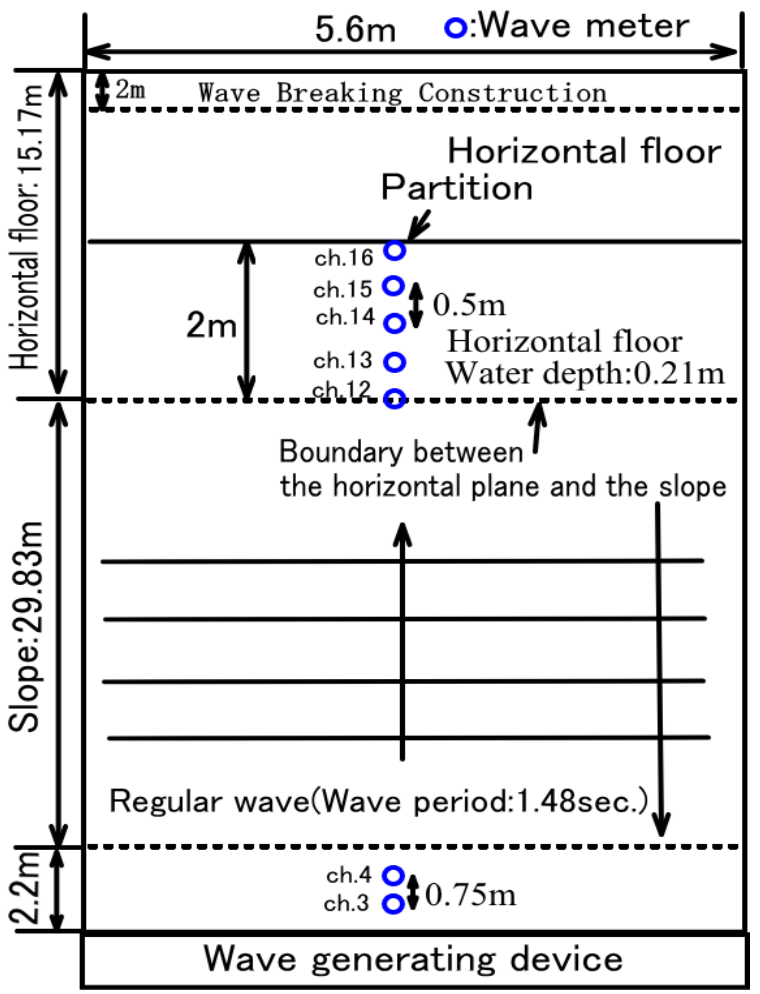

Fig.14 Floor plan of plane water tank in wave generating experiment 1

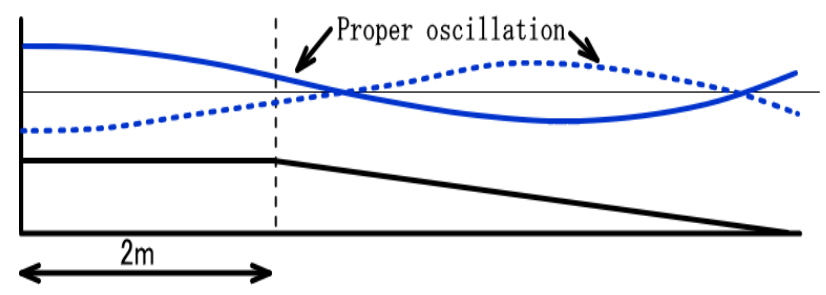

Fig.15 Proper oscillation with period of $9.1 \mathrm{sec}$. and $3 \mathrm{~mm}$ amplitude on the horizontal floor

Wave period: $1.48 \mathrm{sec}$, Wave height: $11 \mathrm{~cm}$ Blue:TimeA, Black:TimeB, Purple:TimeC

Fig.16 Power spectra of water level of channel 16 in wave generating experiment 1 


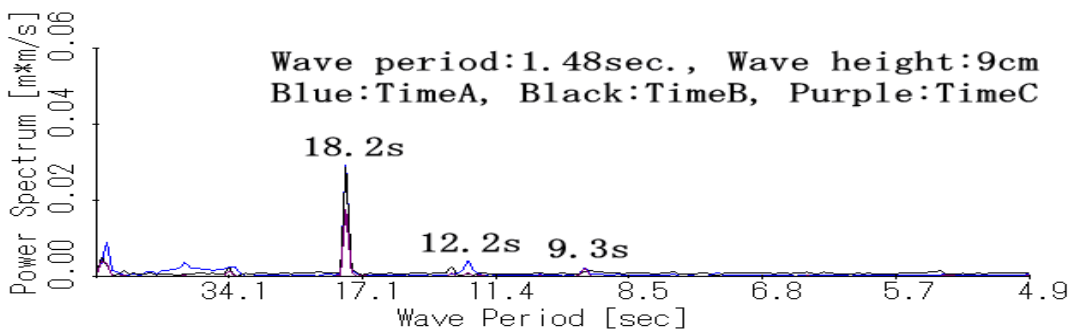

(a)Spectra with periods of $18.2 \mathrm{sec}, 12.2 \mathrm{sec}$ and $9.3 \mathrm{sec}$.

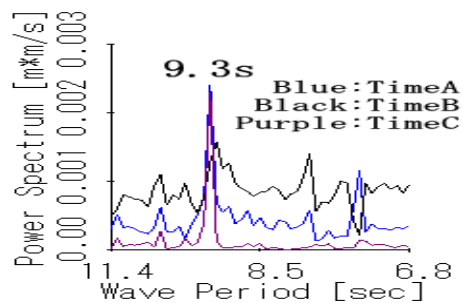

(b)Spectra with period of $9.3 \mathrm{sec}$,

Fig.17 Power spectra of water level of channel 16 in wave generating experiment 1

この波は、勾配 $1 / 100$ の斜面上での固有振動と 思われるが、斜面上の水位データがないため詳細 には分からない。また、9.1 秒周期の波について は、波高 $6 \mathrm{~mm}$ 程度で、Fig. 15 に示寸様にほぼ水平 床上で振動していることが分かった。さらにこの 場合、水位に約 18 秒周期のビート現象 (Fig. 18 参 照)が生じている。このビート現象は、1.48 秒周 期の波と 1.61 秒、 1.37 秒周期の波 (Fig. 19 参照) の相互作用である。1.61 秒と 1.37 秒周期の波は、 1.48 秒周期の波と 18.2 秒周期の固有振動の相互 作用により生じたと思われる。

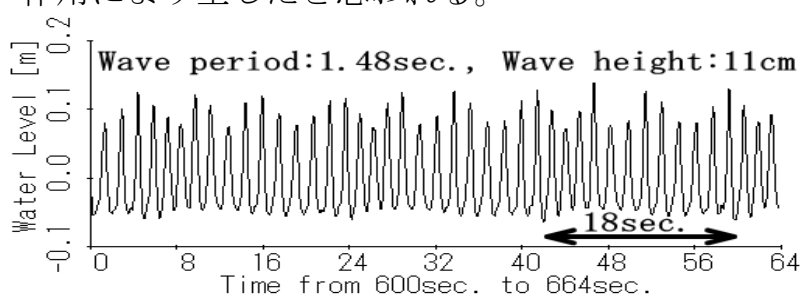

Fig.18 Water level of channel 14 in wave

generating experiment 1

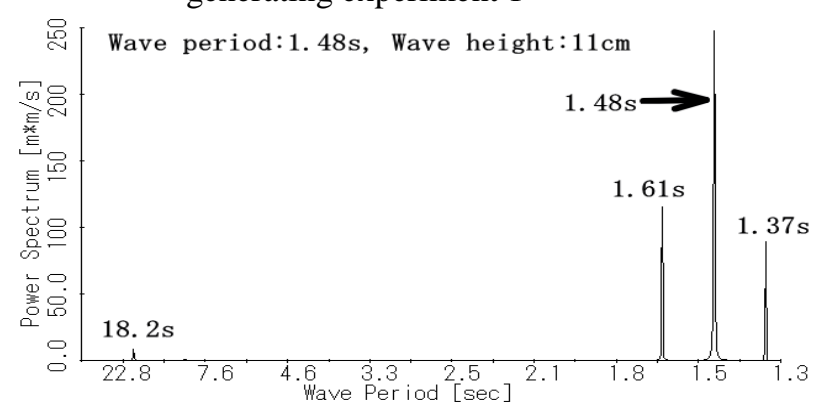

Fig.19 Power spectra of water level of channel

14 in wave generating experiment 1

次に、周期 1.48 秒、波高 $9 \mathrm{~cm}$ の規則波を水平床 に入射して得られた水位データをスペクトル解析 した結果をFig. 17 に示す。Fig. 17 より、波高 $9 \mathrm{~cm}$ の規則波の場合、固有振動は非常に小さく、18.2 秒と 12.2 秒周期の固有振動は時間とともに減衰 していたが、9. 3 秒周期の固有振動は、いったん 時間とともに減衰した後、再び成長していた。こ れは、波高 $7 \mathrm{~cm}$ 、周期 1.48 秒の規則波を入射した
場合も同梯であった。18.2 秒周期の波は斜面上、 9.3 秒周期の波は水平床上の固有振動であると考 えられるが、初期(時間 A) に存在してやがて減衰 して消滅する 12.2 秒周期の波については、どの様 な波なのかよく分からない。

さらに、Fig. 16 と Fig. 17 から入射する規則波 の波高が浅瀬域の水深の $1 / 2$ 以下になると浅瀬域 における固有振動が急に小さくなることが分かる。 これは、浅瀬域における固有振動は、う衫り性波 浪の波高の 2 倍程度より浅い領域で生じているこ とを示していると考えられる。

\section{2 造波実験 2}

造波実験 2 は、水平浅瀬域が沖合に突き出た地 形を想定したものであり、Fig. 20 に示寸様に、幅 $2 \mathrm{~m}$ 、長さ $2 \mathrm{~m}$ 、水深 $0.16 \mathrm{~m}$ の水平床を設置し、この 水平床に周期 1.48 秒、波高 $5 \mathrm{~cm} \sim 11 \mathrm{~cm}$ の規則波を

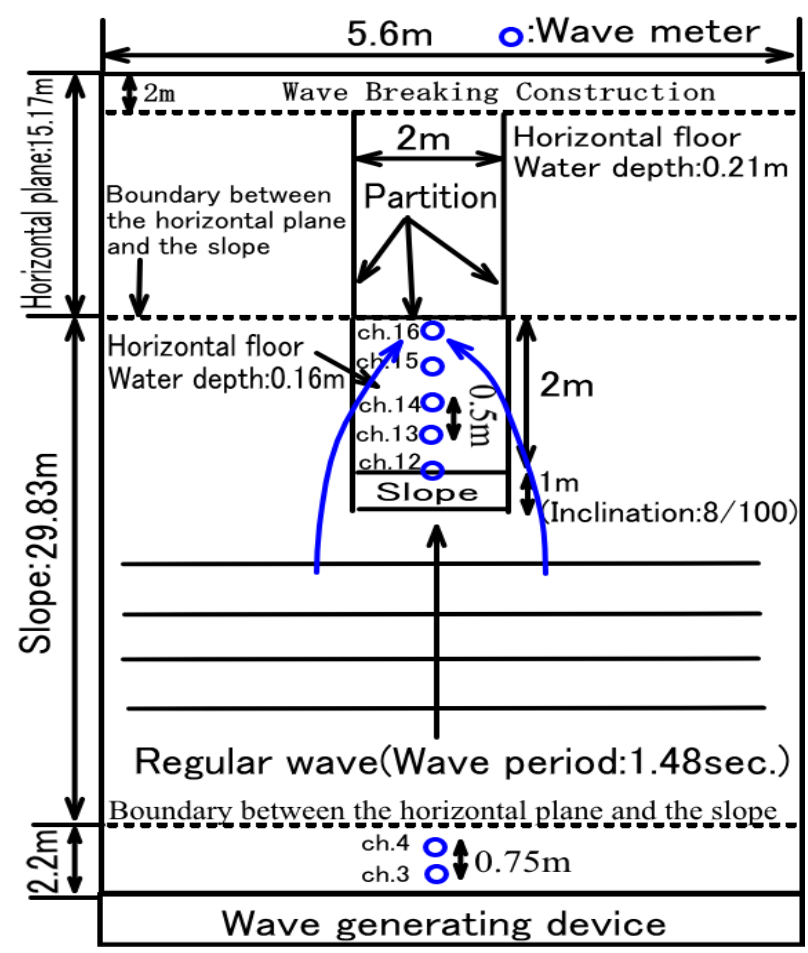

Fig.20 Floor plan of plane water tank in wave generating experiment 2 


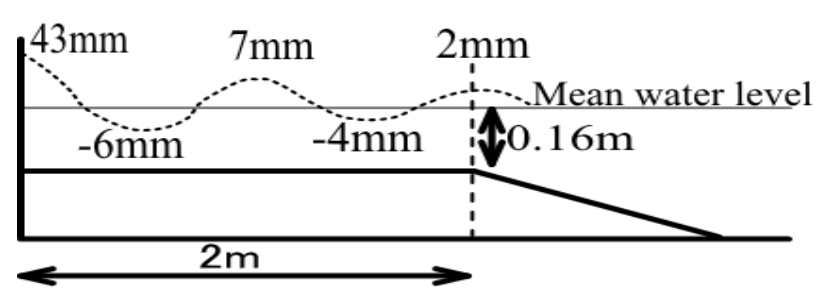

Fig.21 Fluctuation of mean water level on horizontal floor

Table 1 Mean water level on horizontal floor in Time $\mathrm{C}$

\begin{tabular}{|c|c|c|c|c|c|c|}
\hline & $\operatorname{ch} 16$ & ch15 & ch14 & $\operatorname{ch} 13$ & ch12 \\
\hline \multirow{2}{*}{$\frac{\vec{r}}{\frac{\vec{c}}{\mathrm{c}}}$} & $5 \mathrm{~cm}$ & $11 \mathrm{~mm}$ & $-3 \mathrm{~mm}$ & $3 \mathrm{~mm}$ & $-3 \mathrm{~mm}$ & $2 \mathrm{~mm}$ \\
\hline & $7 \mathrm{~cm}$ & $43 \mathrm{~mm}$ & $-6 \mathrm{~mm}$ & $7 \mathrm{~mm}$ & $-4 \mathrm{~mm}$ & $2 \mathrm{~mm}$ \\
\hline \multirow{2}{*}{ 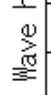 } & $9 \mathrm{~cm}$ & $23 \mathrm{~mm}$ & $6 \mathrm{~mm}$ & $7 \mathrm{~mm}$ & $-5 \mathrm{~mm}$ & $2 \mathrm{~mm}$ \\
\hline & $11 \mathrm{~cm}$ & $27 \mathrm{~mm}$ & $-2 \mathrm{~mm}$ & $6 \mathrm{~mm}$ & $-5 \mathrm{~mm}$ & $3 \mathrm{~mm}$ \\
\hline
\end{tabular}

入射させた。この波の水平床上の長さは約 $1.8 \mathrm{~m}$ となる。また、本実験で想定する縮尺は 1/100 で ある。水平床上および沖合の波浪計設置位置を Fig. 20 に示す。造波実験 2 では、水平床上の固有 振動は確認できなかったが、水深 $0.16 \mathrm{~m}$ の水平床 上の平均水位が、Fig. 21 に示すように場所によっ て変化していることが明らかになった。平均床上 の時間 C における平均水位を Table 1 に示す。

水平床上の波長は約 $1.8 \mathrm{~m}$ であり、ch16、ch14 では、入射波と反射波がほぼ同位相となって波高 が増大し、ch15 と ch13 では逆に打ち消しあうと 思われる。それらの例として、ch12 と ch13 の水 位をFig. 22 と Fig. 23 に示す。また、水平床上で は、屈折により波が集まってくるために波高が増 大している。Fig. 24 に示すようにch16 における 波高は、 $40 \mathrm{~cm}$ 程度 (入射波高の $5 、 6$ 倍) に増大し ている。これは、周囲から波が集まり、さらに、 入射波と反射波が重なった結果であると考えられ る。

この水平床上における平均水位の場所による変 化は、波高 $7 \mathrm{~cm}$ の規則波を入射した場合が最も大 きく、ch16 で+43mm、ch15 で-6mm、ch14 で $7 \mathrm{~mm}$ 、 ch13 で-4mm、ch12 で $2 \mathrm{~mm}$ であった。また、岸側

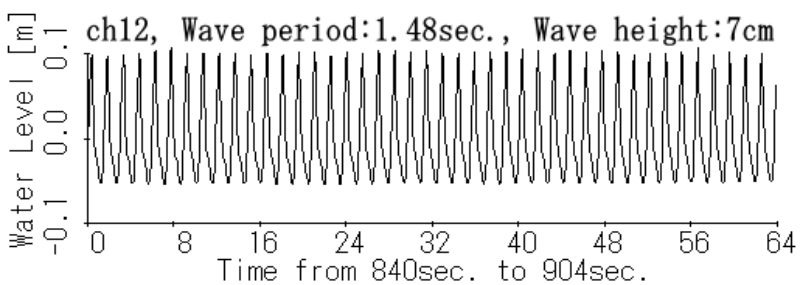

Fig.22 Water level of channel 12 in wave generating experiment 2

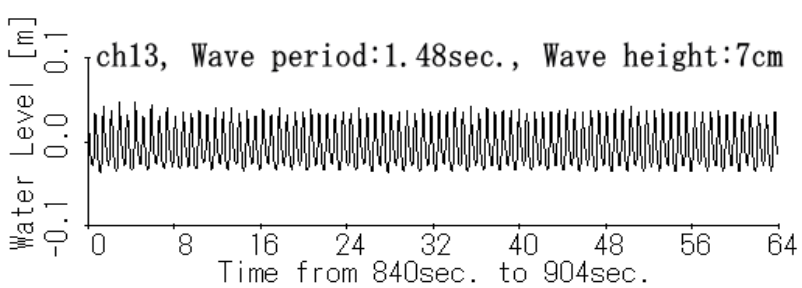

Fig.23 Water level of channel 13 in wave generating experiment 2

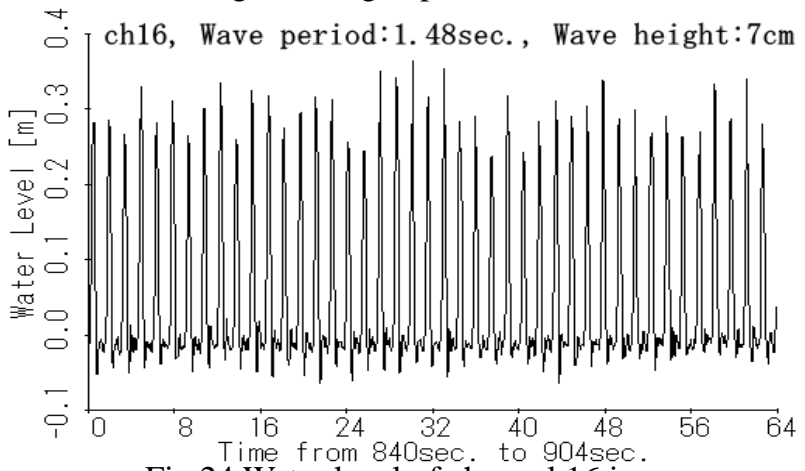

Fig. 24 Water level of channel 16 in wave

generating experiment 2

(ch16)の波高も波高 $7 \mathrm{~cm}$ の規則波を入射した場 合が最も大きかった。波高 $7 \mathrm{~cm}$ の場合、ch16の水 位は $43 \mathrm{~mm}$ となっており、これは沖合に突き出た長 さ $200 \mathrm{~m}$ 四方、水深 $16 \mathrm{~m}$ の水平浅瀬域に波長 $300 \mathrm{~m}$ 、 波高 $7 \mathrm{~m}$ の波が侵入した場合、岸側の平均水位が約 $4 \mathrm{~m}$ 上昇することを意味している。

平均水位の変化については、合田による一様斜 面上の水位変化図 ${ }^{(5)}$ や、高山・神山・菊地による リーフ上の波高算定式 ${ }^{(6)}$ 等があるが、いずれも数 $\mathrm{cm}$ の平均水位上昇を説明することはできない。本 実験における平均水位の上昇を説明するためには、 新しい平均水位上昇計算式を提案する必要がある。

\section{6. おわりに}

本研究では、富山湾沿岸部における水位観測、 および造波水槽を用いた実験により、うねり性波 浪の侵入に伴い沿岸部で生じる数分周期の水位変 動について調べた。そして、4. $4 \mathrm{~km}$ 離れた海底地 形の異なる 2 地点 (水深約 $20 \mathrm{~m}$ と約 $10 \mathrm{~m}$ ) における 水位観測より、次のことが分かった。

（1）沿岸部における数分周期の水位変動 (長周期 波) は、う补り性波浪が沿岸部のなだらかな水平浅 瀬域に侵入し変形、砕波する過程で、水平浅瀬域 において生じた固有振動であると考えることがで きる。

また、造波実験より次のことを確認した。

（1）勾配 $1 / 3.8$ の斜面に続く、長さ $2 \mathrm{~m}$ 、水深 $0.2 \mathrm{~m}$ 
の水平床に、周期 1.51 秒 (波長 $3 \mathrm{~m}$ )、波高 $9 \mathrm{~cm}$ の 規則波を入射させることにより、水平床上で周期 6.7 秒の水位変動 (固有振動) が生じる。これは、 勾配 $1 / 3.8$ の斜面に続く、長さ $200 \mathrm{~m}$ 、水深 $20 \mathrm{~m}$ の 水平浅瀬域に波長 $300 \mathrm{~m}$ 、波高 $9 \mathrm{~m}$ のう㸚りが侵入 することにより周期 67 秒の水位変動が生じるこ とを意味している。

(2) 勾配 $1 / 100$ 長さ $19.8 \mathrm{~m}$ に続く長さ $2 \mathrm{~m}$ 、深さ $0.21 \mathrm{~m}$ の水平床に周期 1.48 秒 (波長 $3 \mathrm{~m}$ ) の規則波を 入射させることにより、水平床上で周期約 9 秒と 周期約 18 秒の水位変動 (固有振動) が生じた。周期 約 9 秒の水位変動は、水平床上で岸側を腹 (Anti-node)、水平床と斜面の境界付近を節 (Node) として変動していた。周期約 18 秒の水位変動は、 水平床上で上下に振動しており、これは斜面上で の固有振動と考えられるが、斜面上では水位観測 をしていなかったので詳細は不明である。

(3) 水深 $0.16 \mathrm{~m}$ 、広さ $2 \mathrm{~m}$ 四方の水平床に波長 $3 \mathrm{~m}$ 、 波高 $5 \mathrm{~cm} \sim 11 \mathrm{~cm}$ の規則波を入射すると、水平床上 の平均水位が岸側、中央、および水平床と斜面の 境界上で上昇した。平均水位の上昇は、波高 $7 \mathrm{~cm}$ の規則波 (波高が水深の約 $1 / 2$ ) を入射した時が最 も大きく、岸側で $4.3 \mathrm{~cm}$ 上昇していた。さらに、 岸側において、波高が入射波高の $5 、 6$ 倍になっ ていた。これは、水深 $16 \mathrm{~m} 、 200 \mathrm{~m}$ 四方の水平浅瀬 域に波長 $300 \mathrm{~m}$ 、波高 $7 \mathrm{~m}$ のう叔り性波浪が侵入す ると、岸側の平均水位が約 $4 \mathrm{~m}$ 上昇し、波高が約 40m になることを意味している。

富山湾沿岸に押し寄せるう称り性波浪の有義波 高は一般に $5 \mathrm{~m}$ 程度であり、う衫り性波浪の侵入に より水深 $10 \mathrm{~m}$ 程度以下の水平浅瀬域で、数分周期 の固有振動が生じていると思われる。そして、こ の水平浅瀬域にう㸚り性波浪が侵入することによ り生じる数分周期の固有振動は、船舶の走錨に重 要な影響を及ぼしていると思われる。さらに、富 山湾沿岸ではう䄈り性波浪による越波発生機構の 解明とその対策が重要である(7)。富山湾沿岸では、 水橋、滑川、芦崎等の沿岸で水深 $10 \mathrm{~m}$ 程度の浅瀬 域が数 $100 \mathrm{~m}$ 程度沖合に突き出た地形になってお り、これらの沿岸に波高 5〜 $7 \mathrm{~m}$ のう称り性波浪が 押し寄せた場合、平均水位が数 $\mathrm{m}$ 上昇している可 能性がある。越波対策を考える場合に、沖合に突 き出た形状の浅瀬域にう䊗り性波浪が侵入するこ とによる沿岸での平均水位の上昇を考慮すること が重要であると思われる。
水平床 (水平浅瀬域)に規則波を侵入させること により生じる水位変動 (固有振動) 、平均水位の場 所による変化、岸側における波高の増大、および ビート現象について、水平床の長さや水深、侵入 させる規則波の波長や波高等を変えて詳しく調心 ること、さらに移動性低気圧による水位変動に伴 う富山湾沿岸部の長周期水位変動について詳しく 調べることは、今後の課題である。

\section{謝辞}

本研究において重要な役割を果たした港湾空港 技術研究所の $35 \mathrm{~m}$ 水路での造波実験を実施して頂 いた、港湾空港技術研究所海洋研究領域波浪研究 チームの平山克也博士、加島寛章博士、長沼淳也 研究官および同研究チームの皆様、さらに、平面 水槽での造波実験の場を提供して頂いた新潟港湾 空港技術調査事務所の松田茂所長をはじめとする 調查事務所の皆様、および(株) 日本港湾コンサル タントの永松宏一部長に心から感謝の意を表する。

本研究は、JSPS 科研費 $15 K 12497$ の助成を受け たものである。

\section{参考文献}

(1) 吉田清三 : 富山湾の海難と寄り回り波, 海難防 止資料, pp. 34-38， 1987.8.

(2) 河合雅司 - 門村英城 : 寄り回り波・津波の予報 に関する基礎研究, 日本航海学会論文集, 第 125 号, pp. 129-135，2011.9.

(3) M.J.Tucker: Surf Beats: Sea Waves of 1 to 5 Min. Period, Proceedings of the Royal Society of London. Series A, Mathematical and Physical Sciences, Vol.202, No.1071, pp. 565-573, 1950.8.

（4）関本恒浩 - 森屋陽一 - 水口優: 自由長周期波の 発生とその定量的評価に関する理論的考察, 海岸工学論文集, 第 47 巻, pp. 236-240, 2000.

（5）合田良実：浅海域における波浪の砕波変形, 港湾技術研究所報告, 第 14 巻, 第 3 号, pp. 59-106, 1975.

（6）高山知司・神山豊・菊地治：リーフ上の波の 変形に関寸る研究, 港研技研資料, No. 278, 1977.

（7）平山克也・加島寛章：下新川海岸に来襲した 長周期う衫りによる越波発生機構の解明とそ の対策, 土木学会論文集 B2 (海岸工学), Vol.67, No. 2, pp. I_106-I_110, 2011. 11. 